\title{
The influence of lectins isolated from pea and soyabean seeds on performance and pancreatic enzyme activity in rats*
}

\author{
J. Czerwiński ${ }^{1,2}$, H. Leontowicz ${ }^{2}$, M. Leontowicz ${ }^{2}$ \\ and R. Krzemiński ${ }^{2}$ \\ ${ }^{1}$ The Kielanowski Institute of Animal Physiology and Nutrition, Polish Academy of Sciences \\ 05-110 Jablonna, Poland \\ ${ }^{2}$ Warsaw Agricultural University, Faculty of Veterinary Medicine, \\ Department of Physiological Sciences \\ Nowoursynowska 159, 02-776 Warszawa, Poland
}

(Received 22 November 2005; revised version 30 May 2006; accepted 6 November 2006)

\begin{abstract}
Lectin extracts were isolated from pea (PSA) and soyabean (SBA) seeds. In agglutination tests with human erythrocytes, SBA lectins showed higher activity than PSA lectins. The highest haemagglutination activity was observed with blood type $\mathrm{AB}, 50 \%$ lower activity with types $\mathrm{A}$ and 0 , and the lowest, with type B.

The experiment was performed on 30 male Wistar rats fed ad libitum a control diet or the same diet supplemented with PSA or SBA at a rate of $15 \mathrm{mg} /$ day/rat for 14 days. Supplementation with lectins had a positive effect on feed intake and body weight gain, which differed significantly in the PSA group and numerically in the SBA group. PSA decreased the amylase activity in pancreatic juice and significantly decreased plasma glucose concentrations. $\mathrm{Ca}, \mathrm{P}, \mathrm{Na}, \mathrm{K}$, and $\mathrm{Cl}$ levels in pancreatic juice were similar in all groups. In rats fed the diets with lectin extracts, total pancreatic trypsin activity was significantly lower than in the control group and numerically lower in pancreatic juice.

The results indicate that the effect of agglutinins from pea and soyabean seeds on pancreatic enzyme activity does not correlate with their agglutination activity.
\end{abstract}

KEY WORDS: lectin, pancreas, amylase activity, trypsin activity, agglutination, rats

\footnotetext{
* Supported by the State Committee for Scientific Research, Grant No. 5 P06E 03708

${ }^{1}$ Corresponding author: e-mail: j.czerwinski@ifzz.pan.pl
} 


\section{INTRODUCTION}

Legume seeds, including soyabean, contain enzyme inhibitors, allergens, lectins and other naturally occurring substances that may influence diet intake, digestibility, absorption and metabolic processes in animals and humans. In animals, the effects of lectins depend on their origin, dose and duration of feeding (Rådberg et al., 2001; Li et al., 2003a,b).

Since some lectins are resistant to digestion, they remain in the digestive tract in the active form for a considerable time. Dietary lectins can interact with nutrients, enzymes, and microflora in the digestive tract and with epithelial cells and can affect metabolic processes upon absorption (Pusztai and Bardocz, 1999). Animals are exposed most often to soyabean lectins, which are present in soyabean meal in amounts ranging from $0.05 \mathrm{mg} / \mathrm{g}$ in normally toasted soyabean meal to $10-20 \mathrm{mg} / \mathrm{g}$ in raw seeds (Schulze et al., 1995), but also to pea lectins due to the relatively high proportion of pea in some pig diets. The content of pea lectin in raw pea seeds ranges from 0.1 to $10 \mathrm{mg} / \mathrm{g}$; Polish pea cultivars contain between 0.27 and 0.75 $\mathrm{mg} / \mathrm{g}$ (Gelencsér et al., 2000)

The destructive effect of high doses of lectins consists in their ability to bind to complementary carbohydrates present on the surface of enterocytes, for example in glycolipids and glycoproteins of the brush border membrane (Bardocz et al., 1999). As a result of enterocyte atrophy, not only is the nutrient absorption surface area reduced, but the transport of nutrients through the epithelium is impeded, which leads to inhibited growth of animals (Pusztai and Bardocz, 1999; Pusztai, 2000). Absorbed lectins may enter the blood stream and therefore affect metabolism in the pancreas and other internal organs. Finally, they can influence the secretion and activity of enzymes. At high doses, lectins can stimulate intestinal and pancreatic overgrowth (Jordinson et al., 1996; Herzig et al., 1997; Grant et al., 2000; Kelsall et al., 2002), diminish enzyme activity (protease, disaccharidase), disturb lipid absorption in the small intestine and modulate insulin, CCK and gastrin secretion (Liener, 1994; Bardocz et al., 1999).

At small doses, lectins can stimulate structural and functional maturation of the gut and pancreatic growth in suckling piglets and rats. This possibility of inducing gut maturation may lead to better adaptation of the piglets to weaning and to an improved growth rate and health status (Rådberg et al., 2001).

The effect of dietary soyabean and bean lectins has been intensively investigated. Only limited data concerning pea lectin is available, however, as only a few studies concerning this lectin have been reported in the literature. Over the past few years, interest in pea lectin has continued to grow. Pea seeds are relatively inexpensive and can substitute soyabean meal in animal nutrition.

In vitro, plant lectins can agglutinate human and animal red blood cells (RBC) (Grant et al., 1995). The strength of lectin adhesion to RBC is similar as to brush 
border membrane (Koninkx, 1995; Bardocz et al., 1999). The agglutination test is often used to compare the activity of lectins.

The aim of this study was to compare the effect of lectin extracts isolated from pea (PSA) and soyabean (SBA) seeds on the performance, pancreatic juice parameters, pancreatic trypsin activity and plasma amylase activity of growing rats.

\section{MATERIAL AND METHODS}

\section{Lectin extraction and agglutination test}

Lectins were extracted from raw pea (Pisum sativum) and soyabean seeds (Glycine max.) according to Santiago et al. (1993). Lectin activity was estimated by the agglutination test (Liener, 1989) with human red blood cells (RBC) of groups $0, \mathrm{~A}, \mathrm{~B}$ and $\mathrm{AB}$.

\section{Animals and diets}

Thirty male Wistar rats weighing 130-140 g were allocated into 3 groups and fed ad libitum a standard diet containing $154 \mathrm{~g}$ crude protein/ $\mathrm{kg}$ (control group) or the same diet with $15 \mathrm{mg} /$ day/rat of a preparation of pea seed agglutinin (PSA) or soyabean agglutinin (SBA) added to the daily ration. The composition of the diet used in the experiment is shown in Table 1. The animals were kept in

Table 1. Composition of standard diet

\begin{tabular}{lr}
\hline Component & $\mathrm{g} / \mathrm{kg}$ \\
\hline Wheat & 304.6 \\
Maize & 157.2 \\
Barley & 143.7 \\
Wheat bran & 100.6 \\
Skim milk powder & 71.8 \\
Fish meal & 57.4 \\
Grass meal & 31.6 \\
Oat flakes & 28.7 \\
Soyabean meal & 28.7 \\
Fodder yeast & 28.7 \\
Linseeds & 8.8 \\
Limestone & 16.1 \\
Mineral-vitamin premix & 10.0 \\
Dicalcium phosphate & 9.2 \\
NaCl & 2.9 \\
Crude protein, analysed & 153.8 \\
\hline
\end{tabular}


individual cages in an air-conditioned room at $21-22^{\circ} \mathrm{C}$ and $12 \mathrm{~h}$ light-dark cycle. Feed intake and body weight were measured for 14 days. At the end of the experiment the rats were anaesthetized by an intraperitoneal injection of uretan $(1.8 \mathrm{~g} / \mathrm{kg} \mathrm{BW})$. The gut was dissected and a catheter introduced into the common pancreatic-bile duct. Pancreatic juice was collected for $1 \mathrm{~h}$. Blood samples were taken from the heart and centrifuged at $4000 \mathrm{~g}$ for $10 \mathrm{~min}$. The rats were sacrificed, the pancreas excised, and $2 \mathrm{~g}$ of pancreas were homogenized with $1 \mathrm{ml}$ physiologic solution and centrifuged at $3000 \mathrm{~g}$ for $10 \mathrm{~min}$. Pancreatic juice, blood plasma, and pancreatic supernatant were frozen at $-20^{\circ} \mathrm{C}$ until analysis.

\section{Analytical methods}

The pancreatic juice was analysed for protein content by the method of Lowry et al. (1951), trypsin activity by the method Erlanger et al. (1961), $\alpha$-amylase activity, by enzymatic methods using Pointe Scientific kits, $\mathrm{Ca}, \mathrm{Na}, \mathrm{K}$ and $\mathrm{Cl}$ content, by using Pointe Scientific reagent kits, and $\mathrm{P}$ content, by using Analco GBG kits. Blood plasma was analysed for protein and glucose content by enzymatic methods using Alpha Diagnostics kits and $\alpha$-amylase activity. The protein content and trypsin activity were measured in the pancreatic supernatant.

\section{Statistical analysis}

The results were subjected to one-way analysis of variance using Statgraphic Plus 5.1. software.

\section{RESULTS}

In the agglutination test with various types of human erythrocytes, the SBA extract showed higher activity than the PSA extract. The highest haemagglutination activity was observed in agglutination of type $\mathrm{AB}$ blood, 50\% lower activity was recorded with type $\mathrm{A}$ and 0 blood, whereas the lowest activity was with type $\mathrm{B}$ blood (Table 2).

Table 2. Haemagglutination titre of human red blood cells by PSA and SBA extract ${ }^{1}$

\begin{tabular}{lrrrr}
\hline \multirow{2}{*}{ Agglutinin } & \multicolumn{5}{c}{ Blood group } \\
\cline { 2 - 5 } & $\mathrm{A}$ & $\mathrm{B}$ & $\mathrm{AB}$ & \multicolumn{1}{c}{0} \\
\hline PSA & 10.00 & 10.00 & 5.00 & 10.00 \\
SBA & 1.25 & 2.50 & 0.62 & 1.25 \\
\hline
\end{tabular}

${ }^{1}$ the result are the lowest concentration of lectin $(\mu \mathrm{g} / \mathrm{ml})$, which showed agglutination 
Feed intake and body weight gain (BWG) were higher in animals fed diets containing PSA or SBA lectins than in controls, while feed and protein efficiency ratios did not differ (Table 3).

Table 3. The influence of PSA and SBA on performance (14 days) in rats

\begin{tabular}{lcccc}
\hline \multirow{2}{*}{ Item } & \multicolumn{3}{c}{ Group } & Pooled \\
\cline { 2 - 4 } & control & PSA & SBA & SEM \\
\hline Feed intake, g/day & $19.1^{\mathrm{a}}$ & $21.6^{\mathrm{b}}$ & $21.1^{\mathrm{ab}}$ & 0.7 \\
Body weight gain, g/day & $4.7^{\mathrm{a}}$ & $6.4^{\mathrm{b}}$ & $5.2^{\mathrm{ab}}$ & 0.4 \\
FER, g feed/g BWG & 4.18 & 3.54 & 4.10 & 0.20 \\
Protein efficiency ratio & 0.86 & 0.73 & 0.84 & 0.04 \\
\hline
\end{tabular}

$\mathrm{a}, \mathrm{b}$ - values within rows with no common superscripts were significantly different at $\mathrm{P} \leq 0.05$

The plasma protein concentrations in group SBA were significantly higher than in the control and PSA groups. The plasma glucose concentration in the PSA group was significantly lower than in the control and SBA groups. In animals from both groups fed lectin-supplemented diets, plasma amylase activity was similar as in animals from the control group (Table 4).

Table 4. The influence of PSA and SBA extracts on amylase activity, protein and glucose level in blood plasma in rats

\begin{tabular}{|c|c|c|c|c|}
\hline \multirow{2}{*}{ Item } & \multicolumn{3}{|c|}{ Group } & \multirow{2}{*}{$\begin{array}{c}\text { Pooled } \\
\text { SEM }\end{array}$} \\
\hline & control & PSA & SBA & \\
\hline Amylase activity, IU/1 & 1022 & 1028 & 963 & 63 \\
\hline Protein, g/l & $55.4^{\mathrm{a}}$ & $53.0^{\mathrm{a}}$ & $60.7^{\mathrm{b}}$ & 1.3 \\
\hline Glucose, $\mathrm{mmol} / \mathrm{l}$ & $12.32^{\mathrm{b}}$ & $9.13^{\mathrm{a}}$ & $11.65^{\mathrm{b}}$ & 0.55 \\
\hline
\end{tabular}

$\mathrm{a}, \mathrm{b}$ - values within rows with no common superscripts were significantly different at $\mathrm{P} \leq 0.05$

In comparison with control rats, the relative weight of the pancreas and protein concentrations were not significantly different in rats fed the diets containing PSA or SBA. Pancreatic trypsin activity was lower in SBA- and PSA-fed rats than in the control group, with the latter difference being significant $(\mathrm{P} \leq 0.05)$ (Table 5).

Table 5. The influence of PSA and SBA extracts on pancreatic parameters in rats

\begin{tabular}{lcccc}
\hline \multirow{2}{*}{ Item } & \multicolumn{3}{c}{ Dietary treatment } & Pooled \\
\cline { 2 - 4 } & control & PSA & SBA & SEM \\
\hline Weight of pancreas, \% BW & 0.36 & 0.34 & 0.34 & 0.02 \\
Protein, mg/pancreas & 9.35 & 10.21 & 7.39 & 0.81 \\
Trypsin activity, U/pancreas & $0.44^{\mathrm{b}}$ & $0.24^{\mathrm{a}}$ & $0.27^{\mathrm{a}}$ & 0.03 \\
Trypsin activity, U/g protein & $47.4^{\mathrm{b}}$ & $24.5^{\mathrm{a}}$ & $36.8^{\mathrm{b}}$ & 3.10 \\
\hline
\end{tabular}

a,b - values within rows with no common superscripts were significantly different at $\mathrm{P} \leq 0.05$ 
Amylase activity in pancreatic juice was higher in SBA- and lower in PSAfed rats in comparison with the control group. The protein, $\mathrm{Ca}, \mathrm{P}, \mathrm{Na}, \mathrm{K}$, and $\mathrm{Cl}$ concentrations and pancreatic juice trypsin activity were similar in all groups (Table 6).

Table 6. The influence of PSA and SBA extracts on pancreatic juice parameters in rats

\begin{tabular}{ccccc}
\hline \multirow{2}{*}{ Item } & \multicolumn{3}{c}{ Dietary treatment } & Pooled \\
\cline { 2 - 4 } & control & PSA & SBA & SEM \\
\hline Amylase activity, 10 ${ }^{3} \mathrm{IU} / 1$ & $80^{\mathrm{ab}}$ & $62^{\mathrm{a}}$ & $129^{\mathrm{b}}$ & 14 \\
Trypsin activity, U/1 & 309 & 294 & 256 & 46 \\
Trypsin activity, U/g protein & 41.7 & 33.1 & 31.6 & 5.1 \\
Protein, g/l & 74.9 & 89.5 & 79.6 & 5.8 \\
mmol/l: $\mathrm{Ca}$ & 2.02 & 2.07 & 1.94 & 0.3 \\
$\mathrm{P}$ & 0.52 & 0.51 & 0.47 & 0.04 \\
$\mathrm{Na}$ & 152 & 150 & 146 & 3.2 \\
$\mathrm{~K}$ & 5.60 & 5.20 & 4.81 & 0.21 \\
$\mathrm{Cl}$ & 100 & 112 & 114 & 6.7 \\
\hline
\end{tabular}

a,b - values within rows with no common superscripts were significantly different at $\mathrm{P} \leq 0.05$

\section{DISCUSSION}

In the present study, agglutination activity depended on the blood group and type of lectin. The SBA extract exhibited greater agglutination activity with various types of human erythrocytes than the PSA extract. The highest agglutination activity was found with blood type AB. This is in agreement with our earlier findings (Czerwiński et al., 2005). Also Koninkx (1995) and Bardocz et al. (1999) reported that the strength of SBA lectin adhesion to Caco-2 cells and to brush border membrane was greater than of PSA.

The anti-nutritional effects of agglutinin are dose-dependent. The dose used in the present study, $0.75 \mathrm{mg} / \mathrm{g}$ diet, was also used in our previous work (Leontowicz et al., 2000; Czerwiński et al., 2005). In an in vitro experiment (unpublished) it was established that $0.75 \mathrm{mg}$ SBA and PSA preparation/g diet corresponded to $0.37 \mathrm{mg}$ of pure lectins/g diet. The results of the current experiment indicate that adding this dose of lectins to the diet did not significantly affect the feed efficiency ratio or protein utilization. Li et al. (2003a,b) showed that doses from 0.1 to $1.2 \mathrm{mg} \mathrm{SBA} / \mathrm{g}$ diet had no significant influence on rat performance, which agrees with results of Leontowicz et al. (2004), our previous study (Czerwiński et al., 2005), and the present results. Bardocz et al. (1999) reported that peanut agglutinin was detected in human blood a few minutes after peanut intake, indicating that absorbed lectins can immediately affect metabolism. According to Liener (1994) and Rådberg et al. (2001) lectins can modulate hormone secretion (insulin, CCK, gastrin). At high 
doses, lectin intake can lead to intestinal and pancreatic overgrowth (Jordinson et al., 1996; Herzig et al., 1997; Grant et al., 2000; Kelsall et al., 2002). Our results showed that the applied doses of PSA and SBA did not result in significant pancreatic overgrowth, which is in agreement with Li et al. (2003a,b) and our previous study (Czerwiński et al., 2005).

In the present study in rats fed diets with lectin extracts, trypsin activity in the pancreas expressed in U/pancreas was lower than in the control group, however, neither lectin significantly decreased trypsin activity in pancreatic juice. Many authors have shown that lectins interacting with brush border membrane can modulate CCK secretion by intestinal endocrine cells (Jordinson et al., 1996; Herzig et al., 1997; Li et al., 2003a,b). Moreover, absorbed lectins can immediately interact with pancreatic cells (Grant et al., 1997; Kelsall et al., 2002). Pancreatic activity can be stimulated in these two different ways. In the present study, SBA increased amylase activity in pancreatic juice, however, the glucose concentration and $\alpha$-amylase activity in plasma did not change. In an in vitro experiment, Grant et al. (1997) found that kidney bean (Phaseolus vulgaris) agglutinin and SBA stimulated amylase secretion from the pancreas and that this stimulation was dose dependent. In the present study, supplementation of the diet with PSA decreased amylase activity in pancreatic juice and significantly decreased the serum glucose concentration, however, this lectin had no effect on $\alpha$-amylase activity in plasma. Leontowicz et al. (2004) also found decreased amylase activity in pancreatic juice in rats fed diets supplemented with evening primrose agglutinin. $\mathrm{Cl}^{-}$ions are necessary for pancreatic amylase activity. The decrease of amylase activity in pancreatic juice in the PSA group was not accompanied by changes in electrolyte levels.

The effect of lectin on metabolism is not irreversible and eased in the course of time (Bardocz et al., 1999). The level of lectins in diets, especially diets rich in pea and soyabean products, depends on the manner of heat processing (Schulze et al., 1995). Morover, not only the dose of lectins, but also intervals between applications should be taken into consideration, which is a relevant issue applicable to animal as well as human nutrition.

\section{CONCLUSIONS}

It can be concluded that agglutinins from pea and soyabean seeds affect feed intake, body weight and enzyme activity. The effect of lectins on pancreatic enzyme activity does not correlate with their agglutination activity. 


\section{REFERENCES}

Bardocz S., Grant G., Pusztai A., Ewen S.W.B., 1999. Lectins as gut growth factors - a summary. In: S. Bardocz, G. Hajós, A. Pusztai (Editors). COST 98. Effects of Antinutrients on the Nutritional Value of Legume Diets. Eur. Commun. 6, 61-64

Czerwiński J., Leontowicz H., Leontowicz M., Gralak M.A., 2005. Response of rats to a moderate intake of soyabean lectin. J. Anim Feed Sci. 14, Suppl. 1, 537-540

Erlanger B.F., Kokowsky N., Cohen W., 1961. The preparation and properties of two new chromogenic substrates of trypsin. Arch. Biochem. Biophys. 95, 271-278

Gelencsér É., Hajós G., Zduńczyk Z., Jędrychowski L., 2000. Content of lectins in respect to the level of protein and other antinutritional factors in Polish pea varieties. Pol. J. Food Nutr. Sci. 9/50, 3S, 91-94

Grant G., Alonso R., Edwards J.E., Murray S., 2000. Dietary soya beans and kidney beans stimulate secretion of cholecystokinin and pancreatic digestive enzymes in 400-day-old Hooded-Lister rats but only soya beans induce growth of the pancreas. Pancreas 20, 305-312

Grant G., Henderson L.T., Edwards J.E., Ewan E.C., Bardocz S., Pusztai A., 1997. Kidney bean and soybean lectins cause enzyme secretion by pancreatic acini in vitro. Life Sci. 60, 1589-1595

Grant G., More L.J., Mc Kenzie N.H., Dorward P.M., Buchan W.C., Telek L., Pusztai A., 1995. Nutritional and haemagglutination properties of several tropical seeds. J. Agr. Sci. 124, 437-445

Herzig K.H., Bardocz S., Grant G., Nustede R., Folsch U.R., Pusztai A., 1997. Red kidney bean lectin is a potent cholecystokinin releasing stimulus in the rat inducing pancreatic growth. Gut 41, 333-338

Jordinson M., Deprez P.H., Playford R.J., Heal S., Freeman T.C., Alison M., Calam J., 1996. Soybean lectin stimulates pancreatic exocrine secretion via CCK-A receptors in rats. Amer. J. Physiol. 270, G653-G659

Kelsall A., Fitzgerald A.J., Howard C.V., Evans R.C., Singh R., Rhodes J.M., Goodlad R.A., 2002. Dietary lectins can stimulate pancreatic growth in the rat. Int. J. Exp. Pathol. 83, 203-208

Koninkx J.F.J.G., 1995. Enterocyte-like Caco-2 cells as a tool to study lectin interaction. In: A. Pusztai, S. Bardocz (Editors). Lectins Biomedical Perspectives. Taylor and Francis Ltd., London, pp. 81-101

Leontowicz H., Leontowicz M., Biernat M., Gralak M., Krzemiński R., Czerwiński J., 2000. The effect of pea lectins on pancreas and jejunum in rats fed semipurified diet. In: S.G. Pierzynowski, J.M. Gee, J. Svendsen (Editors). COST 98. Effects of Antinutrients on the Nutritional Value of Legume Diets. Eur. Commun. 9, 111-115

Leontowicz H., Leontowicz M., Czerwiński J., Kostyra H., Krzemiński R., 2004. Influence of lectins isolated from soyabean seeds and evening primrose seeds and cake on rat metabolism. 4th International Workshop on Antinutritional Factors in Legume Seeds and Oilseeds. EAAP Publication No.110, Toledo (Spain), pp. 115-119

Li Z., Li D., Qiao S., 2003a. Effects of soybean agglutinin on nitrogen metabolism and on characteristics of intestinal tissues and pancreas in rats. Arch. Tierernähr. 57, 369-380

Li Z., Li D., Qiao S., Zhu X., Huang C., 2003b. Anti-nutritional effects of a moderate dose of soybean agglutinin in the rat. Arch. Tierernähr. 57, 267-277

Liener I.E., 1989. Control of antinutritional and toxic factors in oil seeds and legumes. In: W.E.W. Lusas, D.R. Erikson, W. Nip (Editors). Food Uses of Whole Oil and Protein Seeds. Amer. Oil Chem. Soc., pp. 344-371

Liener I.E., 1994. Implication of antinutritional components in soybean foods. Crit. Rev. Food Sci. Nutr. 34, 31-67 
Lowry O.H., Rosebrough A.L., Farr A.J., Randal R.J., 1951. Protein measurement with the Folin phenol reagent. J. Biol. Chem. 193, 265-275

Pusztai A., 2000. Biological effects of plant lectins on the gut: Metabolic consequences and applications. In: S.G. Pierzynowski, J.M. Gee, J. Svendsen (Editors). COST 98. Effects of Antinutrients on the Nutritional Value of Legume Diets. Eur. Commun. 9, 141-142

Pusztai A., Bardocz S., 1999. Lectins in health and therapy. In: S. Bardocz, G. Hajós, A. Pusztai (Editors). COST 98. Effects of Antinutrients on the Nutritional Value of Legume Diets. Eur. Commun. 6, 1-13

Rådberg K., Biernat M., Linderoth A., Zabielski R., Pierzynowski S.G., Weström B.R., 2001. Enteral exposure to crude red kidney bean lectin induces maturation of the gut in suckling pigs. J. Anim. Sci. 79, 2669-2678

Santiago J.G., Levy-Benshimol A., Carmona A., 1993. Effect of Phaseolus vulgaris on glucose absorption, transport and metabolism in rat everted intestinal sacs. J. Nutr. Biochem. 4, 426430

Schulze H., Saini H.S., Huisman J., Hessing M., Berg W.V.D., Verstegen W.A., 1995. Increased nitrogen secretion by inclusion of soya lectin in the diets of pigs. J. Sci. Food Agr. 69, 501-510 